\title{
FINANCIAL SECURITY IN THE SELECTED COUNTRIES AND THE LESSONS FOR VIETNAM
}

\author{
Hương Le Thi Mai \\ Thinh Bui Tien \\ HCMC University of Technology and Education, Ho Chi Minh City, Vietnam \\ Hung Tran Van \\ Vietnam National University of Forestry, Southern Campus, Dong Nai Province, Vietnam
}

Financial security is an issue of concern in many countries as it is responsible for ensuring the financial system is stable, safe and strong. Stemming from this provision, the authors of this article describe the current financial situation in Vietnam and analyze a number of reasons as well as experiences in terms of financial security of several other countries around the world. Based on the aforementioned financial security experiences, lessons are to be drawn for the authorities and policy makers of Vietnam that are responsible for improving the efficiency of national financial security.

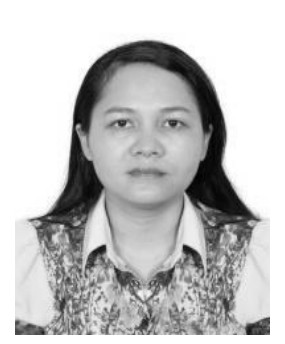

\section{Huong Le Thi Mai}

$\mathrm{PhD}$, Lecturer in Finance, HCMC University of Technology and Education, Ho Chi Minh City, Viet Nam

Research interests: financial sector, banking sector, SMEs functioning and government support, ecological economics, environmental issues of economic development, corporate social responsibility.

E-mail: huongltm@hcmute.edu.vn

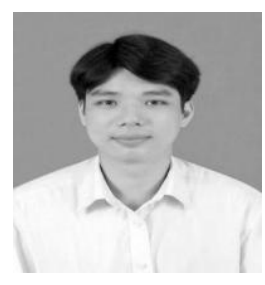

\section{Thinh Bui Tien}

MSc in Applied Economics, Lecturer, Faculty of Economics, Ho Chi Minh City University of Technology and Education, Ho Chi Minh City, Viet Nam

Research interests: economic development, international trade, finance, microfinance.

E-mail: thinhbt@hcmute.edu.vn

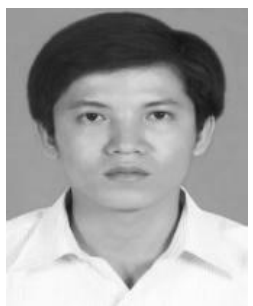

\section{Hung Tran Van}

$\mathrm{PhD}$, Lecturer, Faculty of Economics, Vietnam National University of Forestry, Southern Campus, Dong Nai Province, Viet Nam

Research interests: markets of agricultural products, SMEs functioning and government support, ecological economics, environmental issues of economic development, financial management.

E-mail: hungtv@vnuf2.edu.vn 


\section{FINANCIAL SECURITY IN THE SELECTED COUNTRIES}

Keywords: financial security; financial system; policy-making; Vietnam

\section{Introduction}

Financial security is increasingly becoming a vital issue for all the countries across the globe, especially in the context of rapidly ongoing globalization and economic/financial liberalization. The term "financial security" refers to the situation under which operations of a financial system are conducted in a stable, safe and robust manner. For Vietnam, a country with a socialist-orientation of the market economy, financial security is one of the prerequisites for rapid and stable economic development (Anh, 2017).

Vietnam's financial market is growing rapidly, however, it is also experiencing great challenges in part of ensuring corporate and national financial security. In the context of increasing international economic integration, the instability of the global financial market directly affects currency exchange rates, interest rates, national debt, capital inflows and outflows as well as other risks of Vietnamese financial institutions operating at the financial markets (Mui, 2015).

Many countries around the world have been paying increasingly more attention to the design of their financial security systems, including a number of requirements as follows: (i) A stable financial institution with inter-agency coordination mechanism as a solid legal basis for information exchange; (ii) Empowering government's early intervention policies to deal with troubled banks and to prevent financial system failures; (iii) Empowering the government to handle and resolve the related issues; (iv) Solid deposit design which can act as the ultimate shelter; (v) Availability of government assistance programs. Differences in institutions and other economic characteristics of each country lead to differences in financial policies and financial management implementation.

Financial security experiences from a number of countries around the world can serve lessons for Vietnamese authorities and policymakers that are currently improving the efficiency of the local financial security.

\section{Definition of financial security and criteria of financial security}

\section{Definition of financial security}

According to Anh (2017), financial security is a basic concept referring to a stable, safe and strong financial situation.

\section{Criteria of financial security}

In Vietnam, financial security is based on the criteria of financial safety supervision at the monetary and banking market, stock market and insurance market (Van, 2017). The criteria of financial safety supervision market are as follows:

For the stock market: Financial security is often focused around financial supervision of institutions in the market, as defined in Circular 226/2010/TT-BTC as of 31st December, 2010. Financial supervision regulates financial security norms and measures for stock trading organizations that do not meet financial security norms according to Circular 165/2012 /TTBTC as of 9th October, 2012 including amendments and supplements to a number of articles of Circular 226/2010 / TT-BTC. 
For the insurance market: Supervising the financial security of insurance companies with separate regulations for each type of insurance operations (both life and non-life insurance). These regulations concern reserves, controlling investment levels in assets to ensure the dispersion of risks, regulations on the minimum solvency margin to ensure solvency of insurance companies. In addition, there are also provisions on splitting funds and dividing balance in life insurance.

For the monetary/banking market: International standards under Basel II and the CAMELS system are used to ensure overall security of the banking operations.

\section{Current status of Vietnam's financial security}

For the stock market: According to the State Securities Commission of Vietnam, by the end of 2018, Vietnam's stock market included 697 listed enterprises and 374 companies trading on UPCoM. The market capitalization reached $1,947 \mathrm{trl}$ dong which was the equivalent to $42.3 \%$ of the annual GDP, same year. The bond market in Vietnam in particular performed outstandingly as bonds accounted for 24\% of GDP.

Vietnam's stock market is considered to have the leading growth rate in emerging economies in Southeast Asia and is increasingly confirmed as an important capital mobilization channel of the government. Organizations participating in the market increase rapidly in number, especially securities companies. Their quality, professionalism and performance are increasingly improving as well.

However, the legal framework for the stock market has not yet covered all market activities, several policy mechanisms have not kept up with the movements of transactions, and the supply and demand of goods is always imbalanced.

All of this affects the liquidity. On the other hand, the stock market is a high-level market and operates according to the market principles, but many activities related to trading, issuing securities, interest rates, and price determination mechanisms, bidding mechanism, etc. have not followed these market principles.

This not only affects the performance of the stock market, but also creates a number of potential risks. In addition, the development of corporate bonds is not strong enough to provide enough medium and long-term capital sources for the economy.

Therefore, this source of capital is still mainly supplied by commercial banks (accounting for $86 \%$ ), while over $80 \%$ of the mobilized capital of commercial banks is nonterm and short-term. Commercial banks use $60 \%$ of short-term capital for medium and longterm loans (by the end of December 31, 2018, then downwards) and increase the rate of buying and investing in government bonds as compared to short-term capital of foreign bank branches.

These activities not only pose great risks to the economy and the financial system in general but also to the stock market and commercial banks. In addition, coordination between regulators in managing, directing and monitoring the stock market is not effective enough. The financial market is fragmented and lacks governmental transparency and responsibility on the macro-level of governmental management.

The market information is not always communicated accurately and fully to the investors, while the present psychological factors tend to be heavily dominated by rumors. 


\section{FINANCIAL SECURITY IN THE SELECTED COUNTRIES}

For the insurance market:

The current penetration of insurance in Vietnam is only $2.44 \%$ of GDP which is lower than the average in the ASEAN (3.55\%) or in Asia (5,37\%), and also much lower than the world average $(6.3 \%)$. The potential of this market has not been fully exploited, especially in such its sectors as natural disaster insurance, public property insurance, import/export insurance, life insurance, health insurance and so on (Khanh, 2018).

Despite relatively high growth rates, the size of the insurance market in the country is still small. Several reasons are responsible for that.

The legal system of insurance business is still not consistent with the relevant laws such as the Law on Investment, the Law on Credit Institutions; The Law on Examination and Treatment and the Law on Fire Prevention and Fighting. Secondly, sufficient conditions for insurers to access information in order to control insurance profits have not been created yet. In addition, a number of policies on financial management, taxation and investments have not really encouraged businesses to buy group insurance, life insurance, retirement insurance for employees.

There is no incentive for the insurance companies to expand their business onto remote rural areas or to invest in various social security products. The insurance market still has an unbalanced competition, it also suffers from the lack of cooperation and/or mutual support in information sharing to prevent insurance profiteering. All of these trends taken together reduce the competitiveness and cause extra risks to the market in question. By the end of 2018, Vietnam's insurance market achieved only 50\% compliance with market surveillance standards according to the International Association of Insurance Managers (IAIS).

For the monetary/banking market:

The monetary/banking market in Vietnam has experienced active development in size due to its increasingly important role in regulating capital of the banking system. The creditbanking market experienced a strong growth in size, with the ratio of bank credit to GDP exceeding $110 \%$ of GDP in 2018 and continued to be the dominant market in the system of banking-based finance like Vietnam. Loans from private banks increased more than 7 times in the period of 2007-2018 and is currently the main source of capital for the economy. Four major commercial banks (VCB, BIDV, Vietinbank and Agribank) are dominating Vietnam's credit institutions system today. Together they account for over $50 \%$ of the total credit balance and about $45 \%$ of the total assets.

However, as compared to other countries in the region, the size of the monetary/ banking market in Vietnam is still small. The private credit to GDP ratio of Vietnam is lower than that of Malaysia and Singapore by 20-30 percentage points and then by $36.5 \%$ if compared with Indonesia. The number of ATMs per 100,000 residents shows that the ability to access banking in Vietnam is still relatively low (24 ATMs per 100,000 adults) overall and especially if compared with other countries in the region (59 in Singapore; 52 in Malaysia and 50 in Indonesia).

Vietnam's non-performing loan (NPL) ratio is still quite high as compared to other countries in the region. Vietnam's NPL calculation method is not actually in accordance with the international standards. Thus, strictly speaking, it cannot be used to properly identify the level of risks within the monetary/banking market.

Conventional calculations always show that the reported debts of commercial banks are much lower than those calculated as per international standards. This poses a challenge in 
perfecting Vietnam's NPL calculation, as it needs to be in accordance with the international standards in order to properly identify the level of risks to credit security in the country.

Table 1 - NPL/ Total debt ratio of Vietnam and several other Asian countries (Source: FSIs Database)

\begin{tabular}{|c|c|c|c|c|c|c|c|c|}
\hline$\stackrel{\grave{\Xi}}{\stackrel{\nu}{ }}$ & 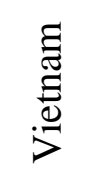 & 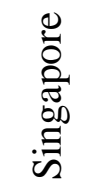 & $\frac{\frac{\pi}{\pi}}{\frac{\pi}{\pi}}$ & 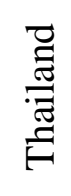 & 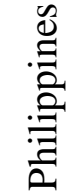 & $\begin{array}{l}\cdot \frac{\sigma}{\tilde{\Xi}} \\
\stackrel{\Xi}{0} \\
\stackrel{0}{\Xi}\end{array}$ & $\begin{array}{l}U \\
\tilde{a}\end{array}$ & $\begin{array}{l}\tilde{\Xi} \\
\stackrel{\Xi}{\Xi} \\
\stackrel{\Xi}{\sigma}\end{array}$ \\
\hline 2010 & 2,1 & 1,4 & 3,4 & 3,9 & 3,4 & 2,5 & 1,1 & 2,5 \\
\hline 2011 & 2,8 & 1,1 & 2,7 & 2,9 & 2,6 & 2,1 & 1,0 & 2,4 \\
\hline 2012 & 3,4 & 1,0 & 2,0 & 2,4 & 2,2 & 1,8 & 1,0 & 2,4 \\
\hline 2013 & 3,1 & 0,9 & 1,8 & 2,3 & 2,4 & 1,7 & 1,0 & 2,3 \\
\hline 2014 & 2,9 & 0,8 & 1,6 & 2,3 & 2,0 & 2,1 & 1,1 & 1,9 \\
\hline 2015 & 2,52 & 0,9 & 1,6 & 2,7 & 1,9 & 2,4 & 1,7 & 1,6 \\
\hline 2016 & 2,58 & 1,1 & 1,7 & 2,9 & 2,0 & 3,0 & 1,7 & 1,5 \\
\hline 2017 & 2,61 & 1,1 & 1,7 & 2,1 & 2,0 & 2,8 & 1,7 & 1,5 \\
\hline 2018 & 2,63 & 1,08 & 1,8 & 2,0 & 2,1 & 2,9 & 1,6 & 1,4 \\
\hline
\end{tabular}

In addition, the monetary/banking market still has many uncertainties. The current supervision is still mainly concentrated around monitoring the compliance, the content of supervision is not comprehensive, and there is a lack of effective tools for risk-based monitoring (Thang, 2016; Thu, 2017).

The credit institutions and the whole system have not been focused on applying quantitative analysis, warning systems' introduction and/or risk verification, so the effectiveness of risk assessment and warning is low. This fact has not contributed positively to enhancing the quality of the system's operations.

The current financial security situation in the aforementioned three areas indicates that the general financial security situation in Vietnam is not yet guaranteed. At the stock market, many activities do not comply with the market principles leading to the operations at this market containing many potential risks.

There are still risks to the insurance market due to the competition of market participants. Particularly, the monetary/banking market still has many potential risks, especially in credit activities. In particular, the NPL ratio is still high, financial and monetary supervision are not effective, so they are not contributing much to financial security of the whole system.

In general, Vietnam has planned a financial strategy to 2020 with the targets to ensure financial security until and after 2020 which were specified in the Strategy and a number of targets have been strategically set (shown in Tab. 1). However, the actual data as of 20112015 showed that these development targets that were supposed to help with ensuring financial security in Vietnam were not achieved as planned. More specifically, the budget revenue from fees and charges reached $21 \%$; the rate of domestic revenue was $68 \%$ and the budget deficit rate was $5 \%$ of GDP which was higher than the planned level of less than $4.5 \%$ of GDP. 


\section{FINANCIAL SECURITY IN THE SELECTED COUNTRIES}

Table 2. Criteria of ensuring financial security of Vietnam, 2011 to 2020

(Sources: Report on financial strategy until 2020. 5-year Development Plan of Vietnam for 2011-2015.

Report on the Strategy for national debt and foreign debt until 2020, Vision for 2030)

\begin{tabular}{|c|c|c|c|}
\hline Criteria & 2011-2015 & $2016-2020$ & After 2020 \\
\hline Revenues from fees and charges & $22-23 \%$ of GDP & $21-22 \%$ of GDP & \\
\hline $\begin{array}{l}\text { Proportion of domestic revenues } \\
\text { (excluding raw oil production) in } \\
\text { the total budget revenues }\end{array}$ & $>70 \%(2015)$ & $>80 \%(2020)$ & \\
\hline Budget deficit rate & $\begin{array}{c}<4,5 \% \text { of GDP } \\
(2015)\end{array}$ & $4 \%$ of GDP & $3 \%$ of GDP \\
\hline Public debt & $\leq 65 \%(2015)$ & $\leq 65 \%(2020)$ & $\leq 60 \%(2030)$ \\
\hline Government debt & $\leq 55 \%(2015)$ & $\leq 55 \%(2020)$ & $\leq 50 \%(2030)$ \\
\hline National foreign debt & $\leq 55 \%(2015)$ & $\leq 50 \%(2020)$ & $\leq 45 \%(2030)$ \\
\hline
\end{tabular}

Thus, the financial security of Vietnam has not been guaranteed, there are many potential risks to the financial system in general (Phan, 2016). The causes can be mentioned as follows:

In recent years, political and economic instability in the world as well as the impact of the global economic cycle along with the crisis at the financial and monetary markets have very strong impacts, thus contributing many actual and potential risks for domestic production and business (Van, 2017). Meanwhile, the domestic economy is still facing difficulties as the quality of the economy has not grown yet, while the public debt has increased rapidly.

The capital market has not yet met the development requirements of the economy, so the banking system is still the main funding channel for investments and development overall. Therefore, the main risks within the financial system are the risks of the banking system. Besides, for many years Vietnamese growth model has been heavily dependable on investments and loans, thus, NPLs present in the economy today are mainly NPLs of the banking system.

Risk management capacities of some credit institutions are rather limited. The internal inspection and control are not good enough, compliance with the existing regulations is not at the required level, ethical standards of banks' officers have not received proper attention. Taken together, all these factors are leading to the emergence of extra risks. Inspection and supervision roles of the State Bank of Vietnam are still limited and have not fully met the requirements of the financial system development.

\section{Financial security experiences of the selected countries}

\section{The United States of America}

Since the banking crisis of 2007-2008, the USA has implemented financial solutions to ensure better security of the financial system in this country. The measures adopted by the US include:

(1) Application of capital requirements under Basel III;

(2) Establishing agreement on one of the two liquidity standards, the liquidity guarantee ratio; 
(3) Progress has been made in implementing requirements to better monitor major global and national financial institutions (G-SIFIs) and countries (D-SIBs), establishing higher ratios capital safety, and also implementing stricter monitoring. A number of reforms and mechanisms (including relief mechanisms/tools) have been implemented so that institutions in danger of disintegration can return to normal operations.

(4) Reform of regulations related to securitization model. Credit rating agencies are now required to make their processes and assessments more publicly transparent; developing regulations on the control of underlying financial assets across different jurisdictions; enhancing accounting information about off-balance sheet amounts such as special investments;

(5) Applying the principles for effective compensation to avoid high risks of investment incentives;

(6) Establishing mutually principle agreement on handling of certain financial transactions in accordance with the American Accounting Principles (GAAP) and the International Financial Reporting Standards (IFRS);

(7) Narrowing the gaps in information about partners and credit risks of important banks in the system;

(8) Reforms concerning derivative products at the OTC market (e.g., central reporting and settlement requirements for some derivative OTC products).

With the aforementioned solutions, the US has achieved certain results in ensuring more secure operation of the financial system. Thus, some of the G20 countries have also applied very similar measures to ensure the security of their financial systems.

\section{Australia}

Since the 2008 global financial crisis, Australia has reformed its financial system to ensure it operates more safely and effectively. In addition to strengthening and other improvements in monitoring of national financial system operations, Australia has established four agencies with clear mandate functions, including:

(1) the Reserve Bank of Australia (RBA) which is implementing monetary policy and monitoring the payment system, acting as the ultimate lender. The RBA is responsible for the overall financial stability across Australia;

(2) Australian Treasury Department;

(3) Australian Prudential Regulation Authority (APRA). It regulates and oversees the banking sector, credit unions, insurance companies;

(4) Australian Securities and Investment Commission.

In addition, in order to ensure more of financial security, this country is paying great attention to coordination mechanisms in information provision. Close coordination between the supervisory agencies in part of information exchange is carried out through the Council of Financial Regulators (CFR).

For deposits, the Financial Claims Scheme (FCS) was established in October 2008 and is now regulated under the Banking Law and administered by the APRA. Depositors are given priority in cases when it is necessary to narrow down / close some of the receiving institutions. This means that depositors have higher compensation than other creditors. 


\section{FINANCIAL SECURITY IN THE SELECTED COUNTRIES}

\section{Russia}

To ensure safer operations of the financial system, the Central Bank of Russia (CBR) plays a decisive role in supervision and settlement of banks and financial institutions. Monitoring measures are decided by CBR. As for the measures related to deposit insurance, the Deposit Insurance Agency (DIA) has the veto power over the proposals of CBR. Accordingly, DIA has the right to agree or disagree to participate in the proposed solution of CBR. In order to take actions and resolve to issue financial security, the CBR has full authority to supervise the financial system with DIA.

Besides the Central Bank, the Deposit Insurance Agency and the Ministry of Finance, the Russian Financial Stability Commission is also part of the financial security network. The Financial Stability Committee provides recommendations and is responsible for effective coordination over the activities related to financial security and anti-crisis measurements.

\section{Indonesia}

In order for the financial system to operate efficiently and safely, Indonesia set up a financial services agency (Otoritas Jasa Keuangan - OJK) to oversee the entire financial sector. Meanwhile, the Bank of Indonesia (BI) has also developed analytical tools for systematic risk assessment and has applied macroprudence tools. The financial security network and management framework were revamped in 2016 according to the Law on Financial Crisis Prevention and Handling. Responsibilities of the relevant agencies in the situation of crisis management have been clarified.

Particularly, the National Financial Stability Committee (KSSK) includes members such as the Minister of Finance as the coordinator and the heads of the Bank of Indonesia (BI), and of the LPS Deposit Insurance Corporation (with membership but without the right to vote). This Commission is responsible for national financial stabilization as well as for identifying and solving failures in major domestic banks so that to avoid the systemic banking crisis. The Commission also recommends the President to announce the state of crisis in the financial system, when needed.

Within this national financial security network, the Central Bank / the Ministry of Finance often plays the leading role in monitoring the system's security with active coordination of other agencies such as the National Financial and Deposit Insurance Supervision Agency. In addition, through the meetings of the Financial Supervisory Commission (which are twice a month) and other high-level bilateral meetings, the Ministry of Finance remains clearly informed about implementation and coordination of measures as well as about their compliance with CBR and DIA policies.

According to the law, CBR is required to share information with DIA. The framework for this information exchange and action coordination between these two agencies was approved back in 2004 .

\section{Bulgaria}

Bulgaria established a financial monitoring system consisting of 4 agencies: (i) The Bulgaria National Bank (BNB) is the central bank responsible for overseeing the banking sector overall; (ii) Financial Supervisory Commission (FSC) is responsible for the investment sector and also for non-bank financial institutions; (iii) The deposit insurance fund supervises the liquidity of banks; (iv) The Ministry of Finance is responsible for policies in the financial sector. 
Bulgaria has also updated its early intervention framework through the application of the European Union (EU) Bank Recovery Directive. Accordingly, Bulgarian governmental departments can direct banks and credit institutions to change their business strategies and/or implement recovery plans when they cannot meet the requirements outlined in the instructions. In the case these interventions are not sufficient to mitigate damaging situations and correct violations, the watchdog may remove or replace some members of the regulatory body. Senior management of a bank, at the same time, can appoint a temporary manager.

\section{Lessons for Vietnam}

Despite remarkable achievements, Vietnamese economy in general and its banking and financial system in particular are still facing many difficulties. In particular, Vietnam is facing risks related to financial security, especially those related to NPL, public debt and state budget deficit.

Stemming from the aforementioned experiences of several selected countries, the authors of this paper propose several recommendations in order to ensure the financial security of Vietnam during the upcoming periods. These recommendations are as follow:

Strengthening measures are needed to ensure that business activities of commercial banks are under strict supervision of the State Bank of Vietnam. This especially concerns the group of ineffective joint-stock commercial banks. Implementing market mechanisms to control and prevent systemic risks in the operation of financial institutions is also needed.

Clearer regulation is required over the information exchange method as well as regulations of the rights and responsibilities of the units within the financial security network. This is for the government and the related offices to be able to intervene early in handling of banking instability incidents.

Minimizing the risks to the banking-dependent financial system by stabilizing the monetary/banking market and handling liquidity risks. At the same time, diversifying forms of capital use to minimize the risks of losses for banks caused by too much focus on credit activities.

Attracting resources to enhance the competitiveness of credit institutions. Mobilizing legal resources by various methods, such as retained earnings, disposing of non-profitable assets, issuing shares to attract more domestic and foreign shareholders or issuing convertible bonds to enhance financial capacity.

All of this is, first of all, to ensure the real capital adequacy ratio according to the Basel 2 standards, to ensure liquidity and to prevent sudden monetary withdrawal or banking system breakdown.

Improving the competitiveness of Vietnamese commercial banks to meet the requirements of stable and efficient development according to international standards and practices. Commercial banks need to develop strategies to increase capital with reasonable use of capital to ensure sustainable capital development.

To conclude, financial security is currently one of the most important issues for many developing economies, including Viet Nam. Ensuring financial security under currently volatile financial activities means to keep the financial system stable, safe and strong and to prevent potential financial crisis situations. 


\section{FINANCIAL SECURITY IN THE SELECTED COUNTRIES}

\section{References:}

Anh, V. D. (2017). Financial security in banking sector. Available: bcsi.edu.vn/.../6_an_ninh_tai_chinh_trong_hoat_dong_ngan_hang.pdf

Khanh, P. N. (2018). Developing the insurance market in Vietnam. Journal of Review of Finance, 01.

Mui, N. T. (2015). Financial monetary security in Vietnam under the changes of international financial monetary market. Journal of Review of Finance, 09.

Thang, V. N. (2016). Financial budget of the 2011 - 2015 orientation and orientation for 2016 2020 period. Available online: http://www.daotaomof.vn/bvct/chi-tiet/349/chuyen-de-3-taichinh-ngan-sach-giai-doan-2011-2015-va-dinh-huong-giai-doan-2016-2020.html

Thu, N.T. (2017). Experiences of national financial security of several countries. Journal of Review of Finance, 09

Phan, D. V. (2016). Experiences of handling financial instabilities of several nations and lessons for Vietnam. Journal of Banking Review, 02.

Van, L. T. T. (2017). Solutions of financial security for Vietnam's financial market. Journal of Review of Finance, 09.

Van, L. T. T. (2017). Developing monetary - banking market in the current globalization and solutions until 2020. Journal of Review of Finance, 02.

Paper submitted

Paper accepted for publishing

Paper published online
22 May 2020

16 August 2020

30 September 2020 